\title{
PRAVNI I EKONOMSKI ASPEKTI KONKURENTNOSTI ORGANSKE PROIZVODNJE U REPUBLICI SRBIJI
}

\author{
Miroslav Čavlin* \\ Univerzitet Privredna akademija u Novom Sadu, \\ Fakultet za ekonomiju i inženjerski menadžment \\ Petar Pejušković \\ Univerziteta Union - Pravni fakultet u Beogradu \\ Svetlana Ignjatijević
}

pored značajnog prirodnog potencijala i rastuće tražnje, proizvodnja organske hrane u Srbiji je još uvek nedovoljno razvijena. Predmet istraživanja u radu je integralna analiza konkurentnosti organske proizvodnje hrane, odnosno definisanje pravnog okvira i ekonomskih mera za unapređenje konkurentnosti organske proizvodnje u Srbiji. Cilj istraživanja je da se sa pravnog i ekonomskog aspekta sagleda strateška pozicija sektora, odnosno mogućnosti i prepreke i predlože konkretne mere za unapređenje poslovanja.

Ključne reči: pravni okvir, ekonomske mere, organska proizvodnja, organska hrana, konkurentnost

\section{Uvod}

Kao reakcija na sve izraženiju ekološku degradaciju, pogoršanje kvaliteta hrane i sve većeg ugrožavanja zdravlja ljudske populacije razvija se organska poljoprivreda. Prema definiciji FAO ${ }^{1} \mathrm{i} \mathrm{WHO}^{2}$ (1999) organska poljoprivreda predstavlja celovit sistem upravljanja proizvodnjom koji promoviše ozdravljenje ekosistema i isključivanje inputa koji ne potiču sa poljoprivrednog gazdinstva, što se postiže maksimalnim korišćenjem agroekonomskih, bioloških i mehaničkih metoda. U većini zemalja, metode organske proizvodnje su zakonski regulisane. Prema tome, organska hrana je ona hrana koja je proizvedena po zakonski definisanim metodama, a njen sastav mora odgovarati opštim zakonima i pravilnicima o kvalitetu hrane kao i kod konvencionalno proizvedene hrane (Renko i Bošnjak, 2009, 371). Srbija je, nakon usvajanja nove regulative u EU, usvojila nov Zakon o organskoj proizvodnji (Službeni glasnik RS broj 30/10) i 1. januara 2011. godine počela sa njegovom primenom. Zakonski okvir čini i Pravilnik o kontroli i sertifikaciji u organskoj proizvodnji i metodama organske proizvodnje (Službeni glasnik RS broj 48/11). Pravilnikom je regulisana proizvodnja, tehnologija prerade, skladištenje, transport, evidentiranje, obeležavanje i sprovođenje kon-

\footnotetext{
* Dr Miroslav Čavlin je vanredni profesor.

${ }^{1}$ Food Agriculture Organization - Međunarodna organizacija za hranu.

${ }^{2}$ World Trade Organization - Svetska trgovinska organizacija.
} 
trole i sertifikacija. Sledeći značajan dokument kojim se uređuje ova oblast je Pravilnik o obliku sadržini, načinu podnošenja i popunjavanja deklaracije i drugih obrazaca u carinskom postupku (Službeni glasnik RS, broj 29/2010) donet i izmenjen od strane Ministarstva finansija. Pravilnikom je konačno omogućeno praćenje izvoza organskih proizvoda. Pravilnikom o korišćenju podsticaja za organsku proizvodnju iz 2014. godine bliže su uređene vrste podsticaja za organsku proizvodnju, uslovi, način i obrasci zahteva za ostvarivanje prava na podsticaje i maksimalni iznos podsticaja po korisniku i po vrsti podsticajne mere

Organska proizvodnja usmerena je na budućnost, i to ne samo sa aspekta bezbednosti hrane i očuvanja životne sredine, već i sa stanovišta ekonomskog prosperiteta. Tražnja za organskim proizvodima na međunarodnom i domaćem tržištu je u stalnom porastu. Međutim, u Srbiji je do sada organska proizvodnja nedovoljno razvijena i ponuda je ograničenog karaktera. Upravo iz tog razloga u radu smo istraživali činioce konkurentnosti organske proizvodnje hrane, odnosno pravni okvir i ekonomske mere za unapređenje konkurentnosti organske proizvodnje u Srbiji sa ciljem da se sagledaju, mogućnosti i prepreke i predlože mere za unapređenje poslovanja. $U$ radu je primenjen komparativni metod gde smo iskustva u organskoj proizvodnji Srbije uporedili sa evropskim, kako bi sagledali sličnosti i razlike.

\section{Pregled stanja razvijenosti sektora organske proizvodnje u Srbiji}

Republika Srbija ima veliki potencijal za razvoj poljoprivredne proizvodnje, a posebno za proizvodnju organske hrane. Povoljna klima I kvalitetno zemljište, sa visokim sadržajem humusa, je osnovni preduslov za razvoj organske proizvodnje hrane. Preko $80 \%$ zemljišta u Srbiji spada u nekontaminirano, jer ne sadrži teške metale i štetne organske materije.

Tabela 1 - Indikatori proizvodnog potencijala organske hrane

\begin{tabular}{|l|l|r|r|r|}
\hline \multicolumn{1}{|c|}{ Zemlja } & Godina & \multicolumn{1}{c|}{$\begin{array}{c}\text { Organsko } \\
\text { poljoprivredno } \\
\text { zemljište (ha) }\end{array}$} & $\begin{array}{l}\text { Udeo u ukupnom } \\
\text { poljoprivrednom } \\
\text { zemljištu (\%) }\end{array}$ & $\begin{array}{c}\text { Broj } \\
\text { proizvođača } \\
\text { organske hrane }\end{array}$ \\
\hline Srbija & 2012. & 11.099 & 0,22 & 0,44 \\
\hline Mađarska & 2015. & 15.298 & 3,000 & 1.617 \\
\hline Rumunija & 2010. & 182.707 & 1,33 & 2.986 \\
\hline Bugarska & 2010. & 25.648 & 0,84 & 709 \\
\hline Makedonija & 2010. & 35.164 & 3,28 & 542 \\
\hline Albanija & 2010. & 284 & 0,02 & 110 \\
\hline Crna Gora & 2010. & 3.561 & 0,69 & 27 \\
\hline BiH & 2010. & 580 & 0,03 & 2986 \\
\hline Hrvatska & 2010. & 23.352 & 1,80 & 21.728 \\
\hline Austrija & 2010. & 538,210 & 22,8 & 21.942 \\
\hline Nemačka & 2010. & 990,702 & 5,9 & 193.042 \\
\hline EU & 2010. & 7.597 .515 & 4,12 & \\
\hline
\end{tabular}

Izvor: IFOAM ${ }^{3}$ i FiBL ${ }^{4}$, Ministry of Life Austria ${ }^{5}$

\footnotetext{
${ }^{3}$ International Federation of Organic Agriculture Movements - Međunarodno udruženje organskih poljoprivrednih pokreta.
} 
Navedeni podaci ukazuju da Srbija u odnosu na susedne nedovoljno koristi bogatstvo koje poseduje. Prema rezultatima istraživanja März i saradnika (2013), u Srbiji je oko 829.000 ha zemljišta namenjeno organskoj proizvodnji, uključujući i površine za prikupljanje divljeg jagodičastog voća, pečuraka i lekovitog bilja. Od toga metode organske proizvodnje primenjuju se na oko 15.298 ha, što predstavlja samo 0,44\% ukupnog poljoprivrednog zemljišta. Nasuprot tome, u Mađarskoj se još 2010. godine, pod organskom proizvodnjom nalazilo čak 127.605 ha ili $3,02 \%$ u odnosu na ukupno poljoprivredno zemljište (tabela 1). Međutim, ohrabrujuća je činjenica da je u Srbiji, u periodu 2006-2015. godine, broj ha pod organskom proizvodnjom povećan na 15.298 ha). U Srbiji je visok broj proizvođača uključenih u sistem organske proizvodnje.

Sa preko 4000 proizvođača, Srbija zauzima vodeće mesto u regionu. Prema podacima registrovanih proizvođača organskih proizvoda u Srbiji ${ }^{6}$ (MPVŠ, 2012), čak 85\% proizvodi proizvode biljnog porekla dok se samo $15 \%$ opredelilo za proizvodnju ribe i mesa na organski način. Takođe, oko 1/3 registrovanih proizvođača se nalazi u Vojvodini koja, uz Zapadnu i Južnu Srbiju, predstavlja najznačajniji region za organsku proizvodnju.

Tabela 2 - Površine prema vrsti organske biljne proizvodnje (2012)

\begin{tabular}{|c|c|c|c|c|}
\hline $\begin{array}{l}\text { Kategorija } \\
\text { proizvoda }\end{array}$ & $\begin{array}{l}\text { Poljoprivredna } \\
\text { kultura (usev) }\end{array}$ & $\begin{array}{c}\text { Površine sa } \\
\text { organskim } \\
\text { statusom (ha) }\end{array}$ & $\begin{array}{l}\text { Površine u } \\
\text { periodu } \\
\text { konverzije (ha) }\end{array}$ & $\begin{array}{l}\text { Ukupne } \\
\text { površine } \\
\text { (ha) }\end{array}$ \\
\hline \multirow[t]{6}{*}{$\begin{array}{l}\text { Višegodišnje } \\
\text { voćne biljne vrste }\end{array}$} & Jabuka & $1.177,55$ & 6,02 & $1.183,57$ \\
\hline & Malina & 550 & 142,46 & 692,46 \\
\hline & Jagoda & 41,42 & 11,54 & 52,96 \\
\hline & Šljiva & $1.188,56$ & 39,48 & $1.228,04$ \\
\hline & Višnja & 409,94 & 26,38 & 436,32 \\
\hline & Ostalo & 686,53 & 865,31 & $1.551,84$ \\
\hline Međuzbir & & 4.054 & $1.091,19$ & $5.145,19$ \\
\hline \multirow[t]{5}{*}{$\begin{array}{l}\text { Jednogodišnje } \\
\text { biljne vrste }\end{array}$} & Kukuruz & 280,37 & 539,33 & 819,7 \\
\hline & Pšenica & 284,66 & 281,72 & 566,38 \\
\hline & Soja & 104,53 & 39,5 & 144,03 \\
\hline & Povrće & 296,5 & 233 & 529,5 \\
\hline & Ostalo & $2.181,47$ & 873,74 & $3.055,21$ \\
\hline Međuzbir & & $3.147,53$ & $1.0967,29$ & $5.114,82$ \\
\hline Pašnjaci & & 20,83 & 818,97 & 839,7 \\
\hline
\end{tabular}

Izvor: März i sar, 2013, str. 13.

\footnotetext{
${ }^{4}$ Research Institute for Organic Agriculture - Institut za istraživanje organske poljoprivrede.

${ }^{5} \mathrm{http}: / / w w w . l e b e n s m i n i s t e r i u m . a t$

${ }^{6}$ U Srbiji je 2012. godine registrovano 317 proizvođača organskih proizvoda.
} 
Podaci u tabeli 2 pokazuju da su u strukturi biljne organske proizvodnje najzastupljenije višegodišnje vrste koje se uzgajaju na oko $46,7 \%$ organski sertifikovanog poljoprivrednog zemljišta. Pod jednogodišnjim kulturama nalazi se samo $46 \%$ površina a ostatak od $7,3 \%$ otpada na livade i pašnjake. U okviru višegodišnjih zasada dominiraju jabuke, šljive i maline, dok se među jednogodišnjim izdvajaju žitarice, soja i povrće.

Tabela 3 - Struktura biljne proizvodnje (ha)

\begin{tabular}{|l|r|r|r|r|r|}
\cline { 2 - 6 } \multicolumn{1}{c|}{} & \multicolumn{1}{c|}{$\mathbf{2 0 1 1 .}$} & \multicolumn{1}{c|}{$\mathbf{2 0 1 2 .}$} & \multicolumn{1}{c|}{$\mathbf{2 0 1 3 .}$} & \multicolumn{1}{c|}{$\mathbf{2 0 1 4 .}$} & \multicolumn{1}{c|}{$\mathbf{2 0 1 5 .}$} \\
\hline Žitarice & $1.211,10$ & $2.522,4$ & $2.273,4$ & $2.818,3$ & 4.252 \\
\hline Industrijsko bilje & 171,90 & 541 & 672,9 & $1.227,8$ & 2.674 \\
\hline Povrće & 75,90 & 113,7 & 106,8 & 153,6 & 170,4 \\
\hline Krmno bilje & 230 & 663 & 594,9 & $1.204,1$ & 1.440 \\
\hline Voće & 1.163 & $1.415,7$ & $1.484,4$ & $1.202,1$ & 2.895 \\
\hline Lekovito i aromatično bilje & 59,5 & 28,4 & 132,6 & 60,9 & 71 \\
\hline Ostalo & 96 & 79,8 & 90,2 & 214,5 & 1.895 \\
\hline
\end{tabular}

Izvor: PKS

Podaci prikazani u tabeli 3 pokazuju značajno povećanje organske biljne proizvodnje u kojoj dominira proizvodnja žitarica i voća, ali i industrijskog bilja.

Analiza podataka prikazanih u tabeli 4. ukazuje na značajno zaostajanje stočarske organske proizvodnje u odnosu na biljnu. U 2015. godini, u odnosu na 2012. godinu, je povećan broj grla krupne stoke i sitne stoke (ovce, koze, svinje). Takođe vidimo da je vrlo malo grla živine i košnica ušlo u proces konverzije, odnosno da je mali broj košnica i živine konačno prevedeno u organski status u 2012. godini.

Tabela 4 - Struktura organske stočarske proizvodnje (2012. i 2015)

\begin{tabular}{|c|c|c|c|c|c|c|}
\hline \multirow[t]{2}{*}{ Kategorija } & \multicolumn{2}{|c|}{$\begin{array}{l}\text { Period konverzije } \\
\text { Broj grla stoka, } \\
\text { jedinki živine i } \\
\text { košnica }\end{array}$} & \multicolumn{2}{|c|}{$\begin{array}{l}\text { Organski status } \\
\text { Broj grla stoke, jedinki } \\
\text { živine, košnica }\end{array}$} & \multicolumn{2}{|c|}{ Ukupno } \\
\hline & 2012. & 2015. & 2012. & 2015. & 2012. & 2015 . \\
\hline $\begin{array}{l}\text { Krupna stoka } \\
\text { (goveda, bivoli, konji, } \\
\text { magarci) }\end{array}$ & 2.164 & 281 & 230 & 2.699 & 2.394 & 2.980 \\
\hline $\begin{array}{l}\text { Sitna stoka } \\
\text { (ovce, koze, svinje) }\end{array}$ & 3.404 & 2.317 & 983 & 4.449 & 4.387 & 6.766 \\
\hline Živina & 4.276 & 301 & 3.600 & 1.079 & 7.876 & 1.380 \\
\hline Košnice & 6.102 & 2.033 & 4.394 & 471 & 7.004 & 2.504 \\
\hline
\end{tabular}

Izvor: März i sar, 2013, str. 14 i PKS 
U okviru organske proizvodnje u Srbiji, zastupljena su tri tipa proizvodnje (Lazić, 2010, 8):

- Male eko farme na kojima su povezane ratarska i stočarska proizvodnja;

- Farme koje se bave samo jednom vrstom proizvodnje (organskim ratarstvom, voćarstvom ili nekim drugim vidom organske proizvodnje);

- Velike eko farme koje čine kombinaciju ratarsko-povrtarske i stočarske proizvodnje.

S obzirom da je prosečna veličina poseda u Srbiji $4 \mathrm{ha}^{7}$, najznačajnija je organska proizvodnja na malom posedu. Na tako malom posedu upravo je to najprofitabilnija proizvodnja. Pri tome se može razviti još jedan tip proizvodnje - multifunkcionalna organska proizvodnja, gde se organskoj hrani specifičnoj za određeni region može dodati i neki drugi nepoljoprivredni proizvod i usluga i to upakovati u jednu agrobioturističku ponudu.

\section{Činioci razvoja ponude proizvođača organske hrane u Srbiji}

Analiza konkurentnosti polazi od proizvođača i prema Rutkauskas $(2008,89)$ potrebna je analiza proizvođača, činilaca i okolnosti koje će uticati na unapređenje konkurentnosti. Kako navode Aguilera-Enriquez, Gonzalez-Adame i Rodriguez-Camacho $(2011,58)$ značajno je ustanoviti postojanje ekonomskih i pravnih interakcija. Autori smatraju da je moguće modernizovati proces upravljanja, odnosno uz ekonomski aspekat potrebno je uključiti i adekvatne principe pravnog stanovištva.

I pored brojnih proizvođača organske hrane u Srbiji kao i rastuće tražnje, ponuda ove vrste proizvoda je još uvek ograničena. Za sada ne postoji dovoljno širok asortiman, količina proizvoda i stalnost u ponudi. Na razvoj ponude domaćih proizvođača organske hrane utiču dve grupe činioca: interni i eksterni.

\section{Eksterni činioci}

Prema Kotleru $(2001,83)$ najvažniji eksterni činioci su: demografski, privredni, politički, pravni okvir, socijalni, kulturni i mikroekonomski.

U cilju stvaranja konkurentne organske proizvodnje potreban je kreativan menadžment, a i država može pozitivno da utiče kreirajući „set zakona i propisa koji promovišu investicije i poboljšanje produktivne efikasnosti. Unapređenje produktivnosti ostvarivo kroz otvaranje privrede i primenu svojinskih prava i zahteva transparentnu vladavinu prava" (Weymouth, Feinberg, 2011, 143). Posebno je značajno normativno urediti polje organske proizvodnje, ne samo zakonima već, i podzakonskim aktima u cilju uspostavljanje celovitog sistema upravljanja i proizvodnje hrane koja je bazirana ekološkoj praksi, visokom stepenu biološke raznovrsnosti, očuvanju prirodnih resursa i primeni visokih standarda o dobrobiti životinja i načina proizvodnje korišćenjem prirodnih supstanci i postupaka.

Demografski činioci, koji nepovoljno utiču na rast ponude organske hrane u Srbiji su: dominantno staro stanovništvo i migracije stanovništva. Stopa prirodnog priraštaja u $\mathrm{Sr}$ biji je negativna i 2011. godine iznosila je $-5,2 \%$. Zbog negativne stope prirodnog priraštaja stanovništvo stari, a posledica toga je ekstenziviranje poljoprivredne proizvodnje.

\footnotetext{
${ }^{7}$ Prema proceni MPŠV prosečna površina poljoprivrednog gazdinstva je 3-5 ha, a komercijalnih 10,6 ha
} 
Naime, stanovništvo Srbije je dve godine starije nego pre jedne decenije, a oko $17 \%$ ukupnog stanovništva ima preko 65 godina (RZS, 2012.). "Prema prosečnoj starosti Srbija se nalazi na petom mestu u Evropi sa negativnom stopom prirodnog priraštaja. Nepovoljna starosna struktura poljoprivrednog stanovništva ograničavajući je faktor razvoja poljoprivrede i sela. Aktivni poljoprivrednici stariji od 65 godina čine 19,6\% ukupne radne snage, a mlađi od 25 godina čine 6,5\%. U EU starosna struktura je povoljnija. Stariji od 65 godina čine $8 \%$, a mlađi od 35 godina čine $25 \%$ ukupne radne snage. Stopa nezaposlenosti mladih u Srbiji sa $48 \%$ je znatno veća u odnosu na EU“ (Raičević, Ignjatijević i Pavlović, 2012, 413). Pored toga masovna migracija iz ruralnih u urbana područja ima društveno-ekonomske posledice. Organska proizvodnja može uticati na zaustavljanje ovih negativnih trendova i kreiranjem dodatnih izvora prihoda uticati na povećanje zaposlenosti. Ribić-Dugandžić $(2007,61)$ ukazuju da ona donosi veću zaradu i zapošljava više radne snage od konvencionalne proizvodnje.

Jedan od najvažnijih političkih činilaca od kojeg zavisi dalji razvoj organske proizvodnje je ulazak Srbije ${ }^{8}$ u Evropsku Uniji (EU). Izvoz na tržište organske hrane ukupne vrednosti 18,1 miliona evra, sa godišnjom stopom rasta od 6,5\% (Willer i Kilcher, 2012) može posebna prilika za dinamičnije uključivanje Srbije u međunarodne tokove. Srbija je učinila značajan korak podnošenjem zahteva za uključivanje u grupu zemalja čiji se proizvodi mogu prodavati u EU.

S obzirom da se oblast konkurencije i komparativnih prednosti procesa i sektora poslovanja smatra sistemom u kome svi privredno-pravni subjekti nastupaju svojom privrednom inicijativom, jasno je da među njima nastaje svojevrsno privredno takmičenje koje je neophodno u svakom slučaju posmatrati dihotomno, odnosno uz ekonomski aspekat uključiti i adekvatne principe pravnog stanovišta (Raičević, Ignjatijević i Matijašević, 2012).

Međutim, liberalizacija trgovine poljoprivredno-prehrambenim proizvodima istovremeno je i pretnja domaćim proizvođačima zbog niskog nivoa konkurentnosti domaće proizvodnje u odnosu na veoma snažnu stranu konkurenciju. S obzirom na proces pristupanja Srbije EU i da je EU dominantan spoljnotrgovinski partner, ključna determinanta izvozne konkurentnosti treba da bude razvijen realni sektora privređivanja. U tom razvoju posebnu prednost treba dati prehrambenoj industriji, što iziskuje poznavanje principa nediskriminacije i osnove zakonskog okvira EU o zaštiti konkurenciji kojeg čine četiri bitna faktora: (Popović, 2005, 238)

Unapređenje organske proizvodnje predviđeno je Nacionalnim akcionim planom, čiji je cilj bio da se do 2014. godine poveća ukupna površina zemljišta u procesu konverzije ili organskom statusu na 50.000 ha. Zakon o organskoj proizvodnji predviđa i podsticajna sredstva proizvođačima organske hrane. U 2010. godini subvencije su iznosile oko milion evra (MPVŠ, 2010). Austrija sa 14\% poljoprivrednih preduzeća predstavlja lidera u EU u oblasti organske poljoprivrede. Proizvođači dobijaju subvencije u okviru nacionalnog Agro-ekološkog programa - ÖPUL "Menadžment organskih farmi". Ukupno 139 miliona EUR ili $26 \%$ ukupnog budžeta „ ÖPUL“ je usmereno organskim poljoprivrednicima. Pored toga, obezbeđene su subvencije za investicije farmerima organske proizvodnje, koji dobijaju oko $20 \%$ sredstava za objekte i opremu naročito prilagođene životinjama, a finansiraju in fondovi Evropske Unije, savezni i regionalni organi Austrije. U Nemačkoj subvencije su po pravilu finansirana od strane Savezne i Regionalne vlade u razmeri 60:40, uz mogućnost sufinansiranja od strane EU fondova. U 2011. proizvodnja poljopri-

\footnotetext{
${ }^{8}$ Početkom 2014. godine Srbija počinje pregovore za članstvo u EU.
} 
vrednih proizvoda iz organske poljoprivrede je podsticana sa oko $€ 143$ miliona iz javnih fondova Nemačke. Prema srednjoročnom planu promocija organske proizvodnje subvencioniše se na način prikazan u Tabeli 5.

Tabela 5 - Plan subvencija u Nemačkoj (2014-2017)

\begin{tabular}{|c|c|c|}
\hline Tip & $\begin{array}{c}\text { Sredstva za uvođenje organske } \\
\text { poljoprivrede po hektaru }\end{array}$ & $\begin{array}{c}\text { Sredstva za zadržavanje organske } \\
\text { poljoprivrede po hektaru }\end{array}$ \\
\hline Povrće & $480 €(575 €)$ & $300 €(350 €)$ \\
\hline Oranica & $210 €(220 €)$ & $170 €(180 €)$ \\
\hline Livada & $210 €(220 €)$ & $170 €(180 €)$ \\
\hline Usevi & $900 €(950 €)$ & $720 €(750 €)$ \\
\hline
\end{tabular}

Izvor: Izveštaj "Federal Ministry of Food, Agriculture and Consumer Protection (BMELV)" Nemačke ${ }^{9}$

U Nemačkoj je $210 €$ po hektaru oranica i livada namenjeno za gazdinstava koji se bave organskom poljoprivredom, a gazdinstva koja održavaju organske poljoprivredu se subvencionišu sa $170 €$ po hektaru. Gazdinstva koja podležu kontroli po EU pravilima mogu dobiti $35 €$ po hektaru, a najviše $530 €$ po farmi. U periodu 2014-2017. godine podrška po ha oranice i livade će biti povećana na $220 €$ po hektaru, dok će se podrška za gazdinstva koja održavaju organsku poljoprivredu povećati na $180 €$ po hektaru. Naknada za troškove inspekcije će biti povećana na $40 €$ po hektaru do maksimalno $550 €$ po gazdinstvu.

Istraživanje podsticaja organske proizvodnje u Srbiji ukazuje da je Uredbom o raspodeli podsticaja u poljoprivredi i ruralnom razvoju u 2016. godini (Sl. glasnik RS, broj 8/16) opredeljeno čak 92.000 .000 dinara. Navodi se da organskoj proizvodnji sleduje $40 \%$ više nego za konvencionalnu proizvodnju. Prema pravilniku o korišćenju podsticaja za organsku proizvodnju predviđena su sledeća sredstva (PKS, Centar za organsku proizvodnju, 11): „osnovni podsticaji u biljnoj proizvodnji u iznosu od 2.800 din/ha; premija za mleko u iznosu od 9,8 din/l; regres za sredstva za ishranu bilja i oplemenjivače zemljišta u iznosu od $14 \mathrm{din} / / \mathrm{kg}$, a najviše $2.800 \mathrm{din} / \mathrm{ha}$; kvalitetne priplodne mlečne krave u iznosu od 35.000 din/grlo; kvalitetne priplodne tovne krave u iznosu od 35.000 din/grlo; kvalitetne priplodne ovce i koze u iznosu od 9.800 din/grlo; kvalitetne priplodne krmače u iznosu od 9.800 din./grlo; roditeljske kokoške teškog tipa u iznosu od 84 din./grlo; roditeljske kokoške lakog tipa u iznosu od 140 din./grlo; roditeljske ćurke u iznosu od 420 din/grlo; kvalitetne priplodne matice riba šarana u iznosu od 700 din/komad; kvalitetne priplodne matice ribe pastrmke u iznosu od 420 din/komad; tov junadi u iznosu od 14.000 din./grlo; tov jagnjadi u iznosu od 2.800 din/grlo; tov svinja u iznosu od 1.400 din; tov jaradi u iznosu od 2.800 din/grlo; krave dojilje u iznosu od 28.000 din/grlo; košnice pčela u iznosu od 840 din/košnica“.

\footnotetext{
${ }^{9} \mathrm{http}: / /$ www.bmelv.de/SharedDocs/Standardartikel/EN/Agriculture/OrganicFarming/OrganicFarminglnGermany.html
} 
U sklopu socio-kulturnih činioca treba ukazati na trend povećanja broja potrošača koji se opredeljuju za novi stil života - "zdrav život". To potvrđuju i rezultati istraživanja sprovedenih na području Srbije prema kojima $50 \%$ ispitanika smatra da su organski proizvodi zdravstveno bezbedni za ishranu, što predstavlja njihov osnovni motiv za potrošnju i kupovinu (Vlahović i saradnici, 2010, 3). Međutim, nivo obaveštenosti, poznavanja i razumevanja značaja organske hrane od strane domaćih potrošača je nedovoljan i negativno utiče na tražnju za ovim proizvodima. Na osnovu istraživanja ${ }^{10}$ u Austriji $50 \%$ kupaca kupuje organske proizvode zato što su "zdravstveno ispravniji", 13\% ima predstavu da kupuje hranu bez "hemijskih aditiva" tj. organsku, $9 \%$ radi podrške organskim proizvođačima, 9\% kupuje radi "boljeg ukusa". Pored navedenog, kupci organskih proizvoda su sigurni da organsko stočarstvo doprinosi očuvanju životne sredine i klime, te na taj način obezbeđuju da i ubuduće hrana neće biti genetski modifikovana.

Poslednji, ali ne i manje važni eksterni činioci razvoja ponude organske hrane su mikroekonomski. Raspoloživost inputa za organsku proizvodnju je svakako značajan preduslov ili prepreka za razvoj ovog vida proizvodnje. Dostupnost semena organskog porekla, bioloških sredstava za zaštitu i sertifikovanog organskog đubriva predstavlja ograničavajući faktor i problem koji treba rešiti u cilju dugoročno konkurentnije organske proizvodnje. Za razliku od dobavljača, posrednici u prometu organskih proizvoda su dobro organizovani, odnosno otkup organske hrane funkcionišu dobro u poređenju sa otkupom proizvoda iz konvencionalne poljoprivredne proizvodnje. U Austriji je od 1995. godine raznim merama intenziviran razvoj organske poljoprivrede. $U$ cilju popularizacije i povećanja potrošnje organskih proizvoda potrošačima su ponuđeni ovi proizvodi u svim prodajnim objektima, a ne samo u specijalizovanim prodavnicama organske hrane. Ovo jasno pokazuje opredeljenje države da organski proizvodi u Austriji ne treba da budu specijalni, već naprotiv proizvodi dostupni svima. Kontinuiranim subvenicoinisanjem organske proizvodnje, država je podsticala posvećenost eko-farmera organskoj proizvodnji i ekološku svest potrošača (posebno da prihvate višu cenu za organske proizvode).

\section{Interni činioci}

U najvažnije interne činioce unapređenja konkurentnosti ponude organske hrane u Srbiji ubrajaju se: marketing, finansije, prerada i organizacija.

Primena marketing koncepta je možda najznačajniji činilac daljeg razvoja ponude organske hrane. Srpski proizvođači ne primenjuju ili ne u dovoljnoj meri primenjuju marketing koncept u svom poslovanju. Kvalitet organske hrane proizvedene u našoj zemlji je na zavidnom nivou. Međutim, kako Ignjatijević i saradnici navode $(2012,1790)$ "...u Srbiji ne postoje marke proizvoda za koje bi se potrošači vezali. Stabilnu tržištu poziciju, prepoznatljivost u okruženju i na međunarodnom tržištu ima mali broj marki proizvoda. Kod nas nije razvijeno shvatanje o značaju stvaranja, postojanja, očuvanja i zaštite marke proizvoda. Usled usitnjene proizvodnje, neadekvatne i promenljive ponude u količini i kvalitetu, skromnog dizajna i pakovanja proizvodi imaju nesiguran plasman na inostrano tržište. Nedostaju sertifikovani proizvodi i mali broj proizvoda je prilagođen novim međunarodnim standardima". Pakovanje do-

\footnotetext{
${ }^{10} \mathrm{http}: / /$ www.lebensministerium.at/en/fields/food/Organicfarming.html
} 
maće organske hrane je manje atraktivno u odnosu na inostranu konkurenciju (Sudarević, 2011) gde su svi organski proizvodi, pored ostalog na odgovarajući način označeni i upakovani. EU je osnovnim standardima regulisala proizvodnju i etiketiranje organskih proizvoda. Dozvoljeno je da proizvođači iz zemalja EU i trećih zemalja dobrovoljno koriste tzv. "Bio-Siegel" etikete. Posebna specifična kvalitativna svojstva, posebnost u proizvodnji određenih poljoprivredno - prehrambenih proizvoda, ističe Ignjatijević i saradnici (2012) moraju biti predmet zaštite oznakom geografskog porekla. Organski proizvodi obeleženi oznakama geografskog porekla potrošačima će garantovati poseban kvalitet i autentičnost proizvoda, zdravstvenu bezbednost i poštovanje zakonskih procedura priznavanja kvaliteta. Srbija kasni sa procesom zaštite pojedinih prehrambenih proizvoda, a veoma je važno da imamo brendirane proizvode. Cena organske hrane, kao drugi instrument marketing miksa, u našoj zemlji je od $20-40 \%$ veća u odnosu na uobičajene proizvode, ali istovremeno niža u odnosu na iste u tržišno razvijenim zemljama. Ovaj nivo cena u kombinaciji sa visokim kvalitetom predstavlja osnovu za uspešno pozicioniranje na međunarodnom tržištu. Troškovi većeg angažovanja radne snage, veći troškovi za zemljište i drugo, čine ove proizvode skupljim, pa npr. Austrija iz poljoprivrednog programa ÖPUL subvencioniše $26 \%$ od ukupnih troškova proizvodnje.

Kanali distribucije i promocija organske hrane u Srbiji su još uvek nedovoljno razvijeni. Ovi proizvodi se uglavnom prodaju preko specijalizovanih prodavnica tzv. „bio-šopova", nekoliko lanaca supermarketa i na zelenim pijacama uz odsustvo internet e-prodaje i direktne prodaje na farmama. S druge strane, oglašavanje nije kontinuirano i sofisticirano i glavna poruka je usmerena na zdravu hranu što zbunjuje potrošače i ograničava pravilno izdvajanje organske hrane na tržištu. Za razliku od evropskih, naši trgovinski lanci nisu spremni da finansiraju dodatne troškove marketinga za proizvode organske proizvodnje. Ujedno, izostaje i podsticaj šireg društvenog značaja, odnosno javna afirmacija organske poljoprivrede u smislu zaštite klime, vode, zemljišta i promocije biodiverziteta.

Finansijski izvori predstavljaju ograničavajući faktor za razvoj organske proizvodnje u Srbiji. Naime, ne postoji ni jedna banka koja nudi posebne kredite za ovu poslovnu aktivnost. Postojeće kreditne linije su nepovoljne u pogledu kamatnih stopa kao i perioda vraćanja. Banke uglavnom odobravaju kratkoročne kredite a organska poljoprivreda zbog specifičnog proizvodnog ciklusa traži dugoročne.

Specifičnost poljoprivrednih proizvoda da se u najvećoj meri moraju prerađivati kako bi zadovoljili zahteve potrošača prisutna je i kod organskih poljoprivrednih proizvoda (Horvat Skenderovič i ostali, 2007, 49). Prerađivačka industrija u domenu organskih poljoprivrednih proizvoda je slabo razvijena i čine je svega 30 prerađivača. Reč je o malim i srednjim preduzećima kojima je prerada ovih proizvoda samo dopunska delatnost. S obzirom da se dodata vrednost ne stvara na nivo poljoprivrednog gazdinstva neophodan je intenzivan razvoj prerađivačkog sektora kao i bolja povezanost sa primarnim proizvođačima. Osim toga, od prerađivača se očekuje poboljšanje efikasnosti proizvodnje i uvođenje i poštovanje međunarodnih standarda kvaliteta.

Organizaciona struktura može se posmatrati kao snaga srpskih proizvođača zato što su mali i izrazito fleksibilni i prilagodljivi tržišnim potrebama. Prema März i saradnicima, $(2013,15)$ preko $60 \%$ gazdinstava koja se bave organskom proizvodnjom imaju manje od 6 ha zemlje. Međutim, njihova veličina negativno utiče na investicionu aktivnost. Poljoprivrednici na malim parcelama nisu motivisani da investiraju u skladišta, opremu za pakovanje i mašine za kultivaciju tla. 


\section{Izvozni potencijal organske hrane proizvedene u Srbiji}

U razvijenim zemljama velika potražnja s jedne strane i zagađenost zemljišta i vazduha s druge strane utiču na nedostatak hrane na evropskom tržištu i izvoznu šansu za Srbiju. Izvozni potencijal srpskih proizvođača organske hrane je praktično neograničen i celokupna proizvodnja bi mogla da se izveze. Zemlje članice EU iz sopstvene proizvodnje podmiruju samo polovinu sopstvenih potreba.

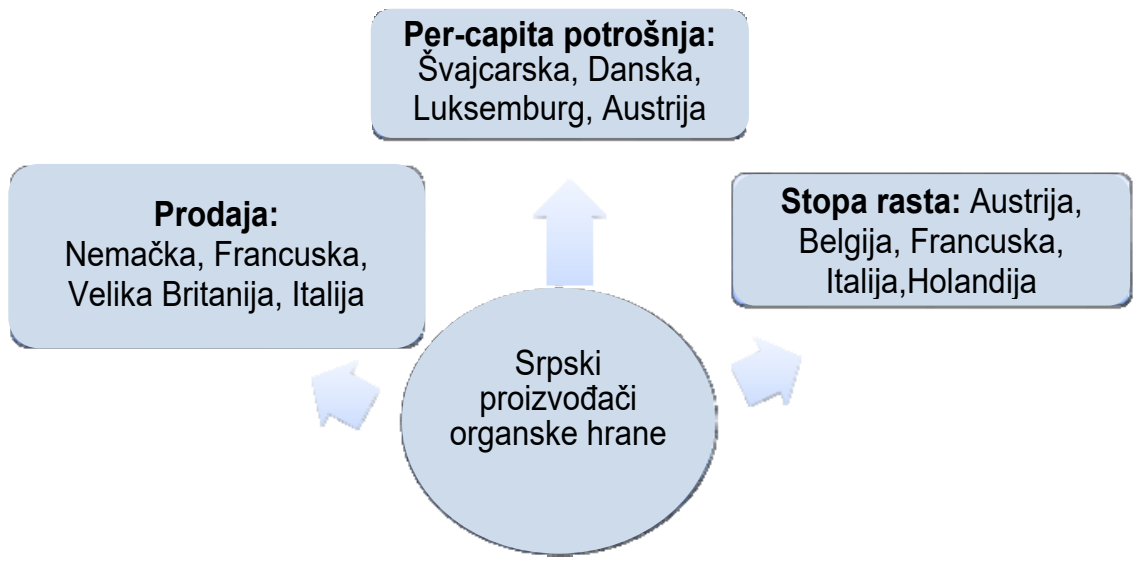

Slika 1 - Potencijalna izvozna tržišta srpskih proizvođača organske hrane Izvor: Rađeno na bazi statističkih podataka Willer i Kilcher, 2012.

Slika 1 prikazuje tri grupe evropskih zemalja na koje treba usmeriti izvoz organske hrane proizvedene u Srbiji. Tržišta koja ostvaruju najveću maloprodajnu vrednost organske hrane su Nemačka, Francuska, Velika Britanija i Italija. Reč je o grupi zemalja koje zajedno čine $66 \%$ ukupne, evropske maloprodajne vrednosti. Drugu grupu čine zemlje sa najvećom per-capita potrošnjom organske hrane kao što su Švajcarska, Danska, Luksemburg i Austrija. U svakoj od ovih zemalja promet po glavi stanovnika dostiže vrednost veću od 100 evra. Kriterijum za formiranje treće grupe zemalja je godišnja stopa rasta tržišta organske hrane. U nekoliko zemalja uključujući Austriju, Belgiju, Francusku, Italiju i Holandiju godišnja stopa rasta je veća od $10 \%$. Većina navedenih zemalja koje čine ove tri grupe predstavljaju ciljna tržišta za domaće proizvođače budući da još uvek ne pokazuju znake zasićenja a pri tome su dovoljno velika da apsorbuju dodatne proizvode.

U Austriji se godišnje izdvaja 8,5 miliona EUR za savetodavne službe, koje pored ostalog imaju "zadatak" da edukuju poljoprivrednike da primene, odnosno povećaju organsku proizvodnju. Sa druge strane posebne mere su usmerene na podsticanje organske ishrane dece i trudnica, te organske ishrane u vrtićima, obdaništima, bolnicama te drugim javnim kuhinjama. Prioritet vladinih mera je usmeren na afirmaciju kombinacije organske hrane i regionalnog porekla i zadovoljstva npr. Geness region Osterreich, 
"Austrian Regionof Delight" - austrijski region zadovoljstva. Nemačka do sada ima najveću potražnju za organskim proizvodima u Evropskoj uniji, a udeo prodaje organske hrane u ukupnom prometu namirnica u Nemačkoj je porastao od € 1,48 milijardi u 1997. na oko $€ 7.04$ milijardi u 2012, što čini 3,7\% tržištu hrane.

Brojni su organski proizvodi iz Srbije sa značajnim tržišnim potencijalom u EU. Organski proizvodi su jedan od najvećih izvoznih potencijala Srbije. U narednom periodu očekuje se nastavak rasta izvoza. Ipak, u izvozu su zastupljeni proizvodi nižeg stepena finalizacije i reč je uglavnom o zamrznutom i pasiranom voću i svežem povrću. U cilju unapređenja konkurentnost organskih proizvoda na inostranom tržištu neophodna su značajna finansijska ulaganja u proizvode veće dodate vrednosti, odnosno višeg stepena prerade. Uz uvođenje sertifikacije i oznake geografskog porekla značajno bi se unapredio sektor organske proizvodnje, odnosno moguće je razmišljati o organskoj poljoprivredi kao prioritetu i nosiocu izvoza srpske poljoprivredne industrije.

Među organskim izvoznim proizvodima posebno se izdvajaju soja, pšenica, kukuruz, ječam, krompir, luk, pasulj, paprika, maline i jabuke. Kako svaki od ovih proizvoda nudi višestruke mogućnosti prerade treba povećati izvoz prerađenih organskih proizvoda. U narednom periodu potrebno je da poljoprivredni proizvođači povećaju produktivnost i ekonomičnost u proizvodnji i obezbede zadovoljavajući kvalitet sirovina. Ignjatijević i saradnici $(2012,1790)$ su ukazali da savremena kretanja u tražnji na tržištu razvijenih zemalja zahtevaju promene u budućem razvoju prehrambene industrije Srbije. Potrebno je u preradi šećera, ulja, žita, voća, povrća i mesa finalizaciju usmeriti u razne finalne proizvode.

\section{Zaključak}

Nema sumnje da je Srbija zemlja sa komparativnim prednostima za razvoj proizvodnje organske hrane. Međutim, zahvaljujući brojnim limitirajućim faktorima na makro i mikro nivou trenutna situacija u ovom sektoru je nepovoljna. Od mnoštvo mera i akcija koje je potrebno činiti za prevazilaženje navedenog stanja prioritet imaju sledeće:

- Povećati finansijsku podršku proizvođačima iz republičkog i lokalnih budžeta;

- Prilagoditi nacionalne pravne okvire da budu transparentni i efikasni;

- Prilagoditi nacionalni pravni okvir u cilju postizanja što višeg stepena efikasnosti u procesu organske proizvodnje i zaštite životne sredine

- Maksimalno koristiti sredstva iz EU predpristupnih fondova, naročito iz IPARD fondova;

- Edukovati proizvođače i širiti mrežu savetodavnih službi;

- Organizovati promotivne kampanje generičkog tipa kako bi se podigla svest potrošača o značaju i karakteristikama organske hrane, posebno za decu i trudnice i korisnike javnih kuhinja;

- Obezbediti proizvodnju semenog i sadnog materijala koji bi koristili organski proizvođači iz Srbije;

- Intenzivnije i uspešnije primenjivati marketing koncept u poslovanju ovih proizvođača kroz prilagođavanje instrumenata marketing miksa zahtevima potrošača (posebno kombinacije regionalnog porekla i organske hrane); 
- Odgovarajućom ekonomskom politikom stvoriti uslove da komercijalno-kreditni sektor odgovori potrebama proizvođača, pre svega za dugoročnim kreditima;

- Podsticati sa pravnog i ekonomskog aspekta formiranje klastera;

- Nastaviti promociju izvoza organske hrane kroz učestvovanje domaćih proizvođača na međunarodnim sajmovima i njihovo brendiranje.

U cilju unapređenja konkurentnosti organske proizvodnje u Srbiji potrebno je regulisati članstvo u Svetskoj trgovinskoj organizaciji, pojednostaviti administrativne procedure po pitanju licenci i sertifikata. U domenu spoljnotrgovinskog poslovanja potrebno je izvršiti usaglašavanje pravnih rešenja unutar pravnog poretka Srbije, a potom taj pravni poredak usaglasiti sa pravom EU, kako bi pravni sistem dobio udeo u ukupnim društvenim okolnostima, koje pomažu investitorima u donošenju odluka za ulaganje u Srbiju.

\section{Literatura}

[1] Aguilera-Enríquez, L., González-Adame, M. \& Rodríguez-Camacho, R. (2011) SMALL BUSINESSES COMPETITIVENESS MODEL FOR STRATEGIC SECTORS, Advances in Competitiveness Research, 19 (3/4), 58-73.

[2] FAO/WHO (1999) Guidelines for the production, processing, labelling and marketing of organically produced foods, Codex Alimentarius Commission, FAO, dostupno dana 20.10.2012. na sajtu: www.codexalimentarius.net/download/standards/360/cxg_032e.pdf

[3] Federal Ministry of Food, Agriculture and Consumer Protection (BMELV), Nemačke, dostupno: http://www.bmelv.de/SharedDocs/Standardartikel/EN/Agriculture/OrganicFarming/OrganicFarmingl nGermany.html

[4] Хорват Скендерович, Т., Новаковић, Н., Пешић Милинко, Н., Сударевић, Т. \& Ковачевић, Б. (2007) Органска производња хране, Суботица, Терра'с

http://www.organic-world.net/statistics-data-tables-dynamic.html?\&L=0

[5] IFOAM i FiBL, (2010) Dynamic Data Table, dostupno dana 22.11.2012.

[6] Игњатијевић, С., Бабовић, Ј. \& Ђорђевић, Д. (2012) Баласа индекс у одређивању компаративних предности пољопривредних производа у извозу, Теме, 36(4), 1783-1800

[7] Котлер, П. (2001) Управљање маркетингом: анализа, планирање, примјена и контрола, 9. издање, Мате, Загреб.

[8] Лазић, Б. (2010) Органска пољопривреда - залог за будућност, Organic news, 1, 8-9

[9] März, U., Stolz, T., Kalentić, M.\&Mišković, N. (2013) Organic Agriculture in Serbia 2013: At a Glance, National Asociation „Serbia Organica“, Beograd.

[10] Министарство пољопривреде, трговине, шумарства и водопривреде (МПШВ), (2010), Уредба о коришћењу подстицајних средстава за подршку развоју органске производње, доступно дана 18.12.1012. на сајту: http://www.mpt.gov.rs/postavljen/126/4827010.0064.41-1.pdf

[11] Министарство пољопривреде, трговине, шумарства и водопривреде (МПШВ), (2012), Списак овлашћених контролних организација за обављање послова контроле и сертификације у органској производњи, доступно на сајту дана 28.11.2012. на сајту: http://www.dnrl.gov.rs/novo\%20organska/odsekzaorganskuproizvodnju/spisakovl2012.pdf

[12] Министарство пољопривреде, трговине, шумарства и водопривреде (МПШВ), (2012), Евиденција произвођача органских производа, доступно дана 25.11.2012. на сајту: http://www.dnrl.gov.rs/novo\%20organska/odsekzaorganskuproizvodnju/evidencijaproiz.pdf

[13] ПКС, Центар за органску производњу, Основне информације о органској производњи у Србији. 
[14] Поповић, М. (2005) Европска унија - ЕУ, Београд.

[15] Правилник о контроли и сертификацији у органској производњи и методама органске производње, Службени гласник РС број 48/11.

[16] Правилник о облику садржини, начину подношења и попуњавања декларације и других образаца у царинском поступку, Службени гласник РС, број 29/2010.

[17] Раичевић, В., Игњатијевић, С. \& Павловић, 3. (2012) Кључне економске и правне детерминанте конкурентности пољопривредне производње. Пословна економија, 6(1), 409-425.

[18] Raičević, V. Ignjatijević, S. \& Matijašević. J. (2012) Economic and legal determinants of export competitiveness of the food industry of Serbia. Industrija 40(1), 201-226.

[19] Ренко, С. \& Бошњак, К. (200.9) Актуелно стање и перспективе развоја тржишта еколошке хране у Хрватској, Економски преглед, 60, 7-8, 369-395.

[20] Републички завод за статистику (2012) Статистички годишњак Републике Србије, доступно дана 05.12.2012. на сајту:

http://webrzs.stat.gov.rs/WebSite/repository/documents/00/00/81/69/02_Stanovnistvo.pdf

[21] Рибић Дуганџић, 3. (2007) Производња еколошке хране у Републици Хрватској с посебним освртом на Међимурје, Магистарски рад, Економски факултет у загребу, Загреб.

[22] Rutkauskas, A. V. (2008) ON THE SUSTAINABILITY OF REGIONAL COMPETITIVENESS DEVELOPMENT CONSIDERING RISK, Baltic Journal on Sustainability, 14 (1), 89-99.

[23] Сударевић, Т. (2011) Економски фактори и маркетинг активности у развоју органске пољопривредне производње, Отворени универзитет, Суботица.

[24] Уредба о расподели подстицаја у пољопривреди и руралном развоју у 2016 години, Службени гласник РС, број 8/16.

[25] Влаховић, Б., Томић, Д. \& Поповић, В. (2011) Стање и перспективе потрошње производа органске пољопривреде, у: Форум о органској производњи, (ИВ), Зборник радова, Селенча.

[26] Weymouth, S.\& Feinberg, R. (2011) National Competitiveness in Comparative Perspective: Evidence from Latin America, Politics \& Society, 53(3), 141-159.

[27] Willer, H. \&Kilcher, L. (Eds.) (2012) The World of Organic Agriculture - Statistics and Emerging Trends 2012, RIOA(FiBL), Frick, and International Federation of Organic Agriculture Movements (IFOAM), Bonn.

[28] Закон о органској производњи, Службени гласник РС број 30/10.

[29] МПВШ (2017) доступно на: http://www.minpolj.gov.rs/ 